\title{
Maternal Accounts of the Costs and Benefits of Life Experiences After Parental Separation ${ }^{1}$
}

\author{
Cheryl Kier \\ Mount Royal College and Athabasca University, Canada \\ Charlie Lewis, and Dennis Hay ${ }^{2}$ \\ Lancaster University, UK
}

\begin{abstract}
Recent analyses both question the assumption that parental separation only has negative effects on families and suggest that attention should be paid to the diversity of experiences post divorce. The latter may be accomplished by combining methods, examining different levels of individuals' experiences. Seventy-six mothers from separated and married families with a child aged 20 months participated in an interview and a life-events questionnaire and these are compared with a range of developmental tests conducted with the mother or child. Separated mothers reported more recent life events than married mothers and rated some more negatively and also others more positively. In regression analyses the only significant predictor of positive life experiences was marital status. Marital status and expressed difficulties in parenting predicted negative life experiences. The results suggest a subtle balance of disadvantages and gains post separation, which must be explored before longitudinal patterns of child and family adjustment are fully understood.
\end{abstract}

Key words: life-experiences; divorce; preschoolers.

\section{Explicações Maternas dos Custos e Benefícios de Experiências de Vida Após Separação Parental}

\begin{abstract}
RESUMO - Análises recentes tanto questionam a suposição de que a separação parental tem efeitos negativos sobre as famílias quanto sugerem que deveria ser dada atenção à diversidade de experiências após o divórcio. Esta sugestão pode ser implementada combinando métodos e examinando diferentes níveis de experiências individuais. Setenta e seis mães provenientes de famílias separadas e casadas, com um de seus filhos possuindo 20 meses de idade, participaram de uma entrevista e responderam um questionário de eventos de vida. Os dados desses instrumentos foram, então, comparados com uma série de testes administrados à mãe ou à criança alvo. As mães separadas relataram mais eventos de vida recentes que as mães casadas e avaliaram alguns eventos mais negativamente e outros mais positivamente. A análise de regressão apontou como único preditor significativo de experiências positivas de vida, o status marital. Status marital e dificuldades na educação e cuidados com a criança predisseram experiências negativas de vida. Os resultados sugerem um equilíbrio sutil de desvantagens e ganhos após a separação, que precisam ser explorados antes que os padrões longitudinais de ajustamentos da família e da criança sejam completamente compreendidos.
\end{abstract}

Palavras-chave: experiências de vida; divórcio; crianças pré-escolares.

Analyses of divorce and marital separation (hereafter referred to as "separation") have long emphasized the negative effects on children and parents (e.g., Wallerstein \& Blakeslee, 1989; Wallerstein, Lewis, \& Blakeslee, 2000). Research over the past decade, however, has increasingly suggested a need to shift attention from a purely pessimistic picture of separation to one which takes into account both the well documented disturbance in children and more general, even positive, changes in family functioning. There are four reasons why this shift appears to have occurred.

1 The authors wish to thank Anne Woollett, two anonymous referees and Dora Dessen for commenting on earlier drafts of this paper, the many people who helped us in recruiting, and the families who participated. We are also grateful to the Department of Psychology at the University of Reading where this research was conducted.

2 Correspondence concerning this article should be addressed to: Charlie Lewis or Dennis Hay. Department of Psychology, Lancaster University, LA1 4YF Lancaster, United Kingdom. E-mail: c.lewis@lancaster.ac.uk
First, it is clear that group differences between separated and "intact" families are actually very small in magnitude. For example, in a meta-analysis, Amato and Keith (1991) revealed that although two-thirds of studies found that children from divorced families had lower levels of well-being than children from married families, the largest effect size was only one-quarter of a standard deviation. Similarly, Allison and Furstenberg (1989) found that marital status accounted for only three percent of the variance in the group differences obtained in their study of more than a thousand children. The same figure of three percent of the variance was obtained in a similar national US survey by Kurdek (1991). More recent analyses (e.g., Hetherington, 1999b; Zill, Morrison, \& Coiro, 1993) suggest that a complexity of factors interact to predict the outcomes of single parenthood, not just separation from one parent.

Secondly, the early 1990s witnessed a trend away from reporting only the negative results of divorce. Guttman (personal communication, July 7, 1994) argued that research- 
ers have asked only certain questions and therefore have interpreted results in limited ways. Olson and Haynes (1993) give a fine example of this when they describe the report by Wallerstein and Blakeslee (1989):

Despite the fact that two-thirds of the women and one-half of the men interviewed felt that they were 'better off' after the divorce, the study focused primarily on the portion of the sample that was ill-adjusted as well as on the children who felt intense bitterness about their life situation. (p. 260)

Thirdly, there has long been a tendency to construct research designs so that any apparent effects of separation are highlighted. Originally, studies tended to compare separated samples with general non-divorced control groups, as if the latter were homogeneous, and assume that any influence on the child is caused by the act of separation. Gately and Schwebel (1992, p. 62) have suggested that "a small yet significant part of the difference may be due to the way science has addressed the question of children's outcomes". They found that parents and clinicians reported more negative effects of divorce on children than children did themselves. Yet, longitudinal data suggest that behaviour problems in children often are displayed several years before the final breakup (e.g., Cherlin, Furstenberg, ChaseLansdale, Kiernan, Robins, Morrison, \& Teitler, 1991). Likewise there is a need to compare separation with staying in conflictual relationships for the sake of their children (Hetherington, 1999b; Jenkins \& Smith, 1993). More recent analyses have attempted to explore the diversity of experiences which contribute to the adjustment of divorce (e.g., Hetherington, 1999a) and the differences between individual families in their adjustment to single parenthood (Emery \& Coiro, 1997).

Fourthly, and perhaps most importantly, researchers have also re-examined the role played by research in popular and political discussion about the status and well-being of the contemporary family. Over the past several years rising divorce rates have been cited as a symptom of wider moral decay. Today's family is often depicted as being in a state of terminal decline. Yet researchers have become increasingly vocal in their opposition to this view. For example, data presented by Rapoport, Rapoport, and Strellitz (1975) and Hernandez (1994) indicate that from the 1930s onwards, only a minority of families have conformed to the "traditional" nuclear pattern of two parents with the father as full-time breadwinner and mother as homemaker. According to Furstenberg (1990), the probability of a child losing a parent (usually due to death rather than divorce) was higher in 1900 than in 1979. As a result of increasing life expectancies, "until death do us part" now means about 40-50 years of marriage whereas in the past this meant only 1520 years of matrimony (Gittins, 1993). Contemporary analyses (e.g., DeGarmo \& Forgatch, 1999) suggest that increasing proportions of children not only experience a separation of their parents but also a succession of possible life experiences including remarriage, the arrival of step siblings and a second parental separation.
It thus seems that slowly researchers have come to acknowledge that some assumptions about family life may no longer be, and may never have been, true (Coontz, 1992). Although negative accounts of divorce and alternative family forms appear to predominate within political and popular debates, in the research community a paradigm shift seems to have been underway for over a decade. As Hutchinson and Spangler-Hirsch (1989, p. 21) suggest, "Viewing the decline of the nuclear family as the main cause of child pathology may be erroneous and may be subject to selffulfilling prophecy properties that are detrimental to the goal of enhancing the well-being of these children". The increasing recognition that marital separation per se may not be cause for "alarm" (Harding, 1993) has led researchers to ask for more attention to be paid to the diversity of experiences and events (e.g., Burghes, 1994; Hetherington, 1999b; Richards \& Schmiege, 1993) and to consider that there may be positive aspects of separation (Schlesinger, 1994; Veevers, 1991). Brown (1994, p. 149) concludes "probably the only consistent finding in studies of families in transition is the great diversity in the responses of parents and children to separation, divorce, and remarriage".

The literature thus suggests that negative experiences associated with separation and divorce may rest upon factors within the family that would be harmful to children regardless of the number of parents in the home. This includes variables such as the quality of the inter-parental and parent-child relationships, which have been well studied. At the same time, the recent literature suggests that external factors which are associated with divorce (but not the divorce itself) have the greatest impact. These involve stressful life experiences (e.g., financial hardship, house moves) and availability of social support. Environmental changes affect child adjustment in both divorced and married families (Amato, 1993; Stolberg \& Anker, 1983), but divorced families tend to undergo more of these experiences (e.g., Forgatch, Patterson, \& Skinner, 1988). While there is a small amount of research showing that positive life events are sometimes correlated with positive aspects of "adjustment" (e.g., Kurdek, 1987; Stolberg \& Anker, 1983), the potential benefits of life events have not been fully investigated. In this paper we will first focus upon four main factors, based upon the research literature about which aspects of divorce most affect custodial mothers and children (following Amato, 1993; Cockett \& Tripp, 1994; Richards, 1995). These will be described below and explored in the main bulk of the paper. This analysis will be followed by a fifth section in which mothers' experiences of life events will be set into a context of changes in the child, mother-child interaction, and the mother herself.

First, there is a need to consider further the relationship between the parents over the period of separation and beyond. This is important because the literature (e.g., Erel \& Burman, 1995) suggests that inter-parental conflict is a major negative influence on children. Children living in families with a high amount of conflict suffer disturbance nearly as frequently as do children with divorced parents (Jenkins 
$\&$ Smith, 1993). Thus, the suggestion that parents should stay together for the sake of the children needs to be explored further. While this debate has lingered for quite some time, there is little consensus as to whether inter-parental conflict increases or decreases after divorce. Recent British evidence suggests that children may be better off living with two parents, but the factors which might influence poorer outcomes for children are still unclear (Rodgers \& Pryor, 1998).

Secondly, there is the issue of parent-child relationships. It is usually assumed that "the family" consists of two parents both of whom are involved in and committed to child care and to one another (van Every, 1991). Thus, researchers have recorded the negative effects of father absence on children (e.g., Wallerstein \& Blakeslee, 1989). Far fewer have questioned the assumption that a present father is necessarily an actively involved, loving, and supportive "role model." Nor is there sufficient exploration of other factors or strategies which mothers may use to compensate for the lack of a biological father in the household. This study responds to the call for an individual differences approach to the functioning of separated families (Emery \& Coiro, 1997).

Thirdly, the issue of financial and housing circumstances post-separation remains on the centre of the agenda (e.g., McLanahan, 1999). Children and their primary caregivers are often said to be affected by a downward spiral of economic circumstances. The effects of poverty are often lauded as being the main cause of problems for these parents, as $80 \%$ of one-parent families in Britain live below the poverty line (Burgoyne, Ormrod, \& Richards, 1987) and similar patterns obtain in other countries (McLanahan, 1999). Yet, few researchers have explored the possibility that mothers and children may become, in some circumstances, financially better off post-divorce (Harding, 1993; Maclean, 1991). Furthermore, criticisms of previous studies include both the reliance upon samples that are poverty-stricken (Blechman, 1982) and samples which are solely middleclass (Kurdek, 1987). Clearly there is a need to include a wide-range of income levels within a single study.

Fourthly, social support is often mentioned as a crucial variable in determining outcomes for parents and children. The association between lone parenting and social isolation is commonly criticised by researchers (Guttman, 1993). While studies have found that divorced mothers receive less practical and social support than other mothers (e.g., Colletta, 1979; Gringlas \& Weinraub, 1995), the literature seems to present this as self evident, so that authors like Summers, Summers, and Ascione (1993, p. 224) can write, "Not surprisingly [italics added], single parents reported significantly lower levels of family support." Researchers do not seem to have been interested in exploring this further, by considering possible variations in family support and their effects on the resident parent's experiences.

The aim of this study is to reconsider the nature of life events associated with marital separation. We examine the experiences of mothers who acquire single parent status after longstanding relationships while their child was in the early preschool years. This group was selected as early par- enthood is noted for its stresses even without the addition of marital separation (Cowan \& Cowan, 1992) and also because paternal residence after divorce is relatively uncommon when the children are so young (Hodges, Landis, Day, \& Oderberg, 1991; Mayes \& Molitor-Siegl, 1999).

In addition to examining each of the four issues just described (the relationship between the parents, the parentchild relationship, their financial and housing situation and social support), the research reported here examines recently separated mothers' responses to a range of recent life events and then sets these with a range of other measures of maternal, child and mother-child adjustment. The main hypothesis tested here was that separated mothers would report more life events and that, in keeping with the recent shift in analyses of divorce, their evaluations in both the Life Events Survey and interviews would reveal a balance of positive and negative effects of experiences in four domains - the ex-spouse relationship, the parent-child relationship, financial and housing circumstances, and social and familial support. The second aim was to explore the links between negative and positive life experiences and both marital status and the other factors listed here: the child's development, the child's temperament, the motherchild attachment, the mother's relationship with the father, and the mother's confidence in her own parenting.

\section{Method}

\section{Participants}

Seventy-six mothers were interviewed from two family circumstances: (a) Separated or divorced families, in which the mothers had been living with a husband or partner for at least five months (mean length of time living with partner $=4.96$ years; $S D=3.44$ years) and who had been separated for at least one month (mean length of time since separation $=13.13$ months; $S D=9.59$ months); (b) Married/cohabiting families in which the mothers were living with the fathers of their children (mean length of time living with children's father $=7.64$ years; $S D=3.25$ years). All mothers were recruited from trawls by Health Visitors (Community Nurses) and the married families were matched in terms of the age of the target child and the neighbourhood of residence. In each group there were 23 girls and 15 boys. Nineteen of the children in the separated families were singletons, compared with 14 children in married group. The mean age of the target child in the separated group was 21.82 months $(S D=9.10)$. Target children in the married group were aged 20.08 months $(S D=7.13)$.

Fathers' occupations ranged from professional/intermediate occupations (39\% of the fathers in the separated group and $63 \%$ of the fathers in the married group) to unskilled workers (3\% of separated fathers but none of the married fathers). Sixty-nine percent of the separated mothers and $84 \%$ of the married mothers had continued schooling beyond the mandatory age of 16 . The Hollingshead Four-Factor Index of Social Status (Hollingshead, 1975) revealed a 
mean rating for separated mothers of $32.95(S D=15.45$; range $=13$ to 66 ). The mean for married mothers was 44.21 $(S D=13.78$; range $=11$ to 66$)$. Thus, while differences between the groups remained, a wide range of socioeconomic groups was represented in both.

\section{Measures and Procedure}

In order to obtain a standardised measure of the stressors experienced by the families over the past 12 months, the mothers completed the Life Events Survey - LES (Sarason, Johnson, \& Siegel, 1978). The LES is a 50-item self-report questionnaire. This measure was chosen because it asks respondents to rate how negatively or positively they viewed each event which they have experienced, rather than having standard weights assigned to every item. This is important because adjustment to stressors may depend on how individuals react to them (see Garmezy \& Rutter, 1983). For example, becoming pregnant may have a different impact on a woman who has been trying to conceive for a long time than for someone who does not wish to have a child. To provide a standard weighting to this event may be misleading. Against each of the fifty items, respondents record whether they have experienced an event and they evaluate its effect on them on a scale from -3 (very negative) through 0 (neutral) to 3 (very positive). Thus the questionnaire gives rise to three change scores: positive, negative, and total (i.e., the total impact of events, with positive and negative combined). Items that referred to marital separation, divorce, or custody were deleted to avoid skewing the results. In addition we examined in more detail those life events which reflected the four themes identified in the Introduction, namely those related to: (a) the relationship between the parents; (b) the financial and housing situation; (c) social support; and (d) parent-child relationships. This enabled us to test whether groups differed on the quantity and perception (positive or negative impact) of these specific life events.

The second procedure was an in-depth maternal interview conducted two weeks after the LES. Mothers completed the LES prior to the interview in order to avoid cueing their responses on the standardised survey. The aim was to consider the issues raised in the standardised measure in greater depth, so that the complexity of experiences, discussed above, could be explored. The interviews were semistructured and consisted of approximately 150 questions. They lasted on average over three hours. (The longest one lasted over eight hours.) Due to the length of some interviews, two sessions were conducted for 14 mothers. A range of items was covered including mother's stress, experiences of bearing and rearing the child, father involvement with child care and household tasks, finances, mother's leisure time, perceptions of the child's temperament, the child's sibling relationships, and other aspects of the mothers' day to day lives. Here we present data from the interviews based on the four themes identified in the Introduction. Following Potter and Wetherell (1987), when the interview mate- rial is unclear and the transcriber is unsure as to its accuracy, round brackets are used. Square brackets indicate where the quotation has been shortened to leave out material in order to increase clarity. Pseudonyms were used for all the family members.

Five further procedures were employed, which set mothers' responses to their life experiences in context:

1. Mother-child attachment. The mother and child attended the University of Reading and underwent the Strange Situation procedure (Ainsworth \& Wittig, 1969). We have reported on this procedure elsewhere and $53 \%$ of separated vs. $68 \%$ of married pairs were rated as secure, but this difference was not statistically significant (see Kier \& Lewis, 1997, for full details).

2. Child intellectual development. The children's intellectual development was tested using the Griffiths Mental Development Scales (1954) which calculate an overall Developmental Quotient based upon five subscales (Locomotor, Personal and Social, Hearing and Speech, Eyehand Coordination, and Performance).

3. Child temperament. The mother completed the Infant Charateristics Questionnaire (Bates, Freedland, \& Lounsbury, 1979) - a standardised measure assessing infant temperament based on four subscales (Fussy-difficult, Unadaptable, Persistent, and Unsociable).

4. Maternal stress. The mother completed the Parenting Stress Index Questionnaire (Abidin, 1982), a standardised measure in three parts, the Child Domain referring to any child behaviours which might make it difficult for any parent to cope, the Mother Domain, examining aspects of parenting in which the mother feels she is not coping, and the Demographic Domain, assessing the stressors on parenting emanating from the mother's environment.

5. The Dyadic Adjustment Scales (Spanier, 1976) assessed the mother's feelings about her relationship with her ex-spouse. It has been used with separated couples and consists of four subscales (Dyadic Satisfaction, Dyadic Cohesion, Dyadic Consensus, and Affective Expression).

\section{Results}

The LES scores were analyzed using t-tests comparing separated and married mothers. On average, separated mothers reported more life events (13.3 events) over the past year than the married mothers experienced ( 5.6 events). This difference was significant, $t(74)=6.04, p<.001$. There was a significant difference for the negative change score, $t$ (74) $=21.42, p<.0001$. Separated mothers scored more highly $(13.1, S D=11.06)$ than the married mothers scored (4.1 points, $S D=4.71)$. The groups also differed on the positive change score, $t(74)=11.00, p<.0001$. The separated mothers' positive change score was 12.11 points $(S D=9.00)$. The positive change score for the married mothers was 6.29 points $(S D=5.99)$. The specific events (related to the four themes raised in the Introduction) were examined together with the information on these issues from the interviews. 


\section{Parents' relationship}

\section{Negative shifts in the relationship between the parents}

The LES data indicated that twenty-four of the 38 separated mothers (63\%) and nine of the 38 married mothers (24\%) identified a major change in the number of arguments with their spouse/ex-spouse over the past 12 months. While 13 of the separated mothers reported that this was a negative experience, nine mothers rated this as positive (two rated it as neutral). Four married mothers rated this change as positive but five rated it as negative. Perhaps unsurprisingly, significantly more separated mothers than married mothers reported this as a negative event (as opposed to not experiencing the event or seeing it as a positive or neutral experience: $\chi^{2}(1, N=76)=4.7, p<.05$. However, the numbers of mothers reporting positive change in their relationships with their ex-spouse should also be noted.

The LES asks respondents whether they have experienced conflicts with their spouse about parenting during the past year. Sixteen separated mothers reported this event. The ratings were 11 negative, four neutral, and one positive. Four married mothers reported this event. Three rated it as negative and one neutral. So significantly more separated mothers recorded negative change, $\chi^{2}(1, N=76)=4.10, p<.05$. However, as noted above, the LES data revealed that for nine separated mothers "spousal" conflict had eased off during the past twelve months. In addition, a fairly large proportion $(24 \%)$ of the married sample reported a change in the number of arguments over the past year. So, the differences between the two groups were not straightforward and it seems to be the case that for some parents separation eases the family from the burden of parental conflict.

Such variations in responses reveal the complexities of separation. For some, conflict over the marital home is crucial. Opportunities for conflict appear to increase during the separation period (prior to the divorce) before property settlements are worked out:

Well it's not like home. I mean I haven't got anything out. All my little ornaments and things are all upstairs in my bedroom because if he [ex-husband] comes - he - he's coming in this weekend because he knows I'm going to stay at my Mum and Dad's. I mean he could take anything. He just takes whatever's there. Or he smashes it. All the time it's my word against his. So, I have to keep everything locked upstairs. [28-year-old with a 14-month-old daughter. She is not working outside the home (henceforth termed 'full-time mother'). Her ex-husband is a company director.]

\section{Parents' relationship may improve post-separation}

While conflict did sometimes continue or escalate after the parents were living apart, the follow up interviews suggested that there were a number of couples for whom conflict and tension disappeared. Thus for some the benefits of separation outweighed the costs, even though the costs were still apparent. (They are not mutually exclusive.) The relief ex- perienced by some mothers now that they were no longer living with their husbands was unmistakable. While married, mothers often spent a lot of energy worrying about what their partners were doing when they were not home as expected.

\begin{abstract}
Once he'd actually moved out, I didn't have to worry about things like why he was home late, you know, who was actually phoning, or who he was phoning or listening in to telephone conversations. And um, or if he was going out with his friends, who he was with and why wasn't I being invited. You know, that all stopped. I mean, then it didn't really matter where he was going. I didn't know about it. And um, that was really quite nice. [30-year-old mother with one daughter aged 23 months. She works as a chiropodist and her ex-husband is a quantity surveyor.]

It's hard at first [adjusting to parenting on her own], but once you get used to the idea and once things get going on your own, it's a lot easier than living with a man you can't live with. [28-year-old full-time mother with a daughter aged 18 months, and three other children. Her ex-husband is in the army.]
\end{abstract}

\section{Parent-child relationship}

\section{Father-child relationship}

Fathers are not necessarily loving, supportive, giving parents just because they are living with the mother of their children. According to the separated mothers, being a father and caring for a baby were not high a priority for their partners when they were living together. When fathers were not reported to be cruel, thoughtless, or aggressive, they often were described as showing little interest in their children - although we have no paternal accounts to corroborate this and our research suggests that mothers and fathers often describe the nonresident father's psychological commitment in radically different ways (Lewis, Papacosta, \& Warin, in press).

There is no item on the LES which examines this issue. In the interviews, mothers were asked about the current contact between the father and child, and the separated mothers were questioned about father involvement with the child before the separation. The responses suggest that during the marriage the (future) separated fathers had less contact with the child than those fathers who remained married. Thirty-four $(89 \%)$ of the married mothers stated that their partners participated in at least some care giving in the past week. Twenty-three (68\%) of the separated mothers reported that their ex-partners engaged in some care giving during an average week when they were living together. This difference is significant, $\chi^{2}(1, N=76)=5.18$, $p<.05$. Although such differences may reflect greater paternal involvement when children move into late infancy/ toddlerhood or maternal bias in reporting, it does suggest that some (future) separated fathers have a remote relationship with the child. Some were reported to conduct their lives as if they did not have a family, and rarely went out of 
their way to spend time with the children. Such a lack of care on the part of the husband was described as even helping a child to cope with father absence:

Don't forget I mean sort of five days a week he wouldn't see her except to kiss her good night. (Interviewer: Because he came home so late.) Yeah. Um, and that would be Saturdays as well. And most Sundays. He'd only have - uh, Sunday he'd be home once a month. So we're not talking very often. It's a very rare occasion that he used to see her. I mean this is why there was no difference when he left. He probably saw her more when he left than when he was here. [28-year-old child minder with a 38-month-old daughter, whose ex-husband is an electrician.]

Mothers reported using a variety of strategies to try to compensate for the absence of the fathers. For example, they tried to keep to rituals and routines, made efforts for their children to spend time with male adults, or gave their children extra attention, even if this involved an element of self sacrifice.

I suppose I might make more of an effort than I used to um, spend time with them. Because I feel I had to make up for time that Graham - well I don't think he actually spent much time with them, but I felt that I had to make up for anything they might be losing on time. [24-year-old full-time mother with two daughters aged 24- and 60-months, whose exhusband is a building site foreman.]

If I do everything for them, and I suffer, I don't mind so much. But if I have to do something for me and they suffer, then I don't do it. I go without and ... and I try to do everything for them....And then whoosh!... you know, no money coming in for a year, and I've had to make the money last to cover one year with no money coming from him. I've had to cope. And the first thing that went was me! You know, no clothes, no goings out, no - no nothing for me. Um, but I must admit at times I sort of look at myself I'm - I - I - I do wish I could go back to caring a lot more for myself. But that does take money. Um, and if I haven't got it, I just can't do it. [35-year-old part-time playgroup worker with two sons aged 42- and 85months, whose ex-husband is a cable company director.]

\section{Fathers may be good role models after separation}

Father presence is no guarantee for father involvement. At the same time, fathers can become more involved with their children after the separation (Kruk, 1991; Smart, 1990), as illustrated by several of the mothers in our sample. Nine of 38 separated mothers $(24 \%)$ reported that while the child's father had not been very involved in child care during the marriage, he had visited the child at least once a month after the breakup. The interviews supported this evidence that some fathers are more involved after than during the marriage:

They get more time now spent with us playing with them because Bill's time when he sees them he just plays with them, he talks to them, whereas when - probably before he'd be that absorbed in watching the television he wouldn't even notice them, you know? [44-year-old year old flight attendant (purser) with two boys aged 34- and 60-months. Her ex-husband is a bricklayer.]
She was really frightened of him. And uh, so to start with, I wouldn't let him see her on his own or anything, you know, I had to be there. But um, she's getting better now. She's got a better relationship with him now. And he comes and um, as I say, he comes and baths her twice a week and he sees her on a Saturday. So she - she knows he's her Daddy now. Which is as it should be.... [28-year-old full-time mother with a 14month-old daughter. Her ex-husband is a company director.]

\section{Housing and financial situation}

\section{Housing and financial problems}

Two questions in the LES addressed these issues. The first concerned house moves. More separated mothers than married mothers had changed residence in the past year (11 vs. 5 , respectively), with ten reporting it as positive and only one negative. Four married mothers rated their house move as being positive and one as neutral. None of the differences was significant. However it was clear from the interviews that the experiences of the two groups were qualitatively different. Unlike the married mothers, the separated mothers tended to talk about matters of relative deprivation, like moving from bed and breakfast accommodation to a (council) flat or house. That, in the interviews, some reported having moved several times is a reflection of the limitations of questionnaires investigating life events. Some separated mothers described a pattern of moves from the familial home to a temporary local authority accommodation, usually Bed and Breakfast, to a bigger place, like a council house. Such detail cannot be collected in standardized questionnaire.

Secondly, the LES revealed that significantly more separated than married mothers experienced a change in financial status in the past year, $\chi^{2}(1, N=76)=4.52, p<.05$. However, the proportion of women who found this to be a negative event was almost equal for the two samples: 19 out of $28(68 \%)$ separated mothers found the change to be negative and 9 out of $16(56 \%)$ married mothers.

For some women it is not the absolute amount of money they possess but the drop in standard of living that makes it difficult for them to adjust. One mother argued that it may be harder for women previously living with middle-class husbands to cope with a low income than for mothers who had been surviving on little money even during their marriages. This has not been sufficiently examined by researchers, but these mothers suggest that it may be an important variable.

I mean I do - I do get by. Uh, but um, with like um luxuries, I don't have the luxuries that I used to. I mean if I wanted something I'd get it [when married]. You know, and I think it's harder for a person [who has had sufficient money during the marriage] to get used to a shorter amount of money than those that are used to a shorter - [amount in the first place]. You know, with being used to having a lot of money, you know and I mean we - we were pretty well off [...] People having a short amount of money and then getting used to being on income 
support [welfare] isn't too bad, I don't think. But that has been a great change for me. [24-year-old full-time mother with a 19-month-old daughter and a 36-month-old son. Her exhusband is a service engineer.]

Mothers were asked in the interview about any problems they were having in bringing up the baby. Eighteen (47\%) of the married sample and $27(71 \%)$ of the separated mothers answered in the affirmative. This difference was statistically significant, $\chi^{2}(1, N=76)=5.12, p<.05$. However, when their reasons for experiencing problems were explored further, the proportions of those experiencing psychological problems (e.g., behavior problems, sleeping difficulties) was equal (42\% for married mothers vs. $49 \%$ for separated mothers). In contrast, those reporting material factors as the cause of their problems (e.g., financial difficulties, poor housing) was greater in the separated group $(51 \%$ vs. $8 \%$ in the married group: NB $29 \%$ of separated and $3 \%$ of married mothers experienced both material and psychological problems).

\section{Finances and / or housing situation may improve post- separation}

While housing and finances were definitely problematic for some mothers, for more (i.e., one third of these reporting a change) the financial situation improved after the separation. These mothers emphasized their greater control over money regardless of any objective increase in income. They often described themselves as financially better off because their husbands had gotten them into debt during the marriage.

[During the marriage,] He took my purse, he took all my - I think we had about 15 pound (about \$15) left for the week, to do our shopping. Um, he took that, he went out there and he blew all that. Um ... we no, we literally didn't have any food in the house or anything. So, I um, see my - went to see my health visitor. Um, and she got me some - got some food and that.... [].... It's nice now. It's not very nice 'cause we're separated, but, it's nice because my money's my own, and if we haven't got any at the end of the week, it's my fault, nobody else's, mine. If we've got food in the cupboard, we've got food in the freezer, um, and the kids very rarely go without. If they want something, then they normally get it. [27-year-old full-time mother not working outside of the home; with two daughters aged 11-months and 25-months and an older son. Her ex-husband works as a chef.]

\section{Social support}

\section{Tensions in the social support system}

On the LES a great many more separated than married women reported a major change in closeness of family members in the past year. Ten rated this change as positive and ten rated it as negative. (Only one married mother recorded this life event and she rated it as positive.) Thus a higher proportion of separated mothers reported positive change, $\chi^{2}(1, N=76)=8.6, p<.005$, or negative change, $\chi^{2}(1, N=$ $76)=11.5, p<.005$. Why did they register such change? In the interview the difference in reported current contact with their own parents was not significant between the groups (64\% of separated and $69 \%$ of married mothers visited their parents regularly). The data suggest two possibilities. Firstly, it may be that in response to a probe in a questionnaire mothers report a general increased closeness with their parents, but it takes more in-depth interviewing to uncover a more complicated set of circumstances. Increased closeness to one's parents may come at a price. The fact that the LES revealed that eight mothers reported experiencing "conflicts with child's grandparents (or other important person) about parenting" is consistent with this (Five married mothers experienced this event):

\begin{abstract}
Although they've been tremendously supportive they stick the knife in a few times... You do feel a failure when your life goes wrong... 'why me?' To feel a failure because your husband's gone is pretty serious, but to have your parents make you feel a failure as well, it cuts all the more deeply. [33-year-old mother had two daughters aged 23- and 62-months and she had an older son. Her employment as a decorator is periodic. Her exhusband is a managing director.]
\end{abstract}

The second possibility is that in completing the questionnaire, participants were not describing the increased closeness that they felt towards their parents but rather towards their own children.

Because I'd always been saying before, 'Well Daddy will do that because ...'. And uh, you know we've had some good times [since the separation]. And I think - I think that's helped us because they have - I think they have a better image of me now. Because like I can put the chain back on the bike or whatever. Which I would have said, not because I couldn't do it, but because I was doing something else, but I would have said, 'When Daddy gets home, he'll do that'. And because you can't say that any more, you have to do things. And uh, they're really chuffed (i.e., pleased) about it. So it's yeah, so that - I think because they're pleased with you, they don't mess you around so much. [37-year-old mother with two daughters aged 22- and 50 -months and a seven-year-old son. She is not currently employed outside the home but is well educated (to degree level) and expects to enter the labour force shortly. Her ex-husband is an electronics engineer.]

\section{Mothers may find new sources of social support}

While some mothers were unable to use their families to support them during their adjustment to the marital separation and some mothers used this support rather reluctantly, others reported that they found new sources of support, or that they found their families to be very comforting. One of the benefits of being separated was their increased opportunities for leisure activities. Many felt that the separation allowed them to engage in more outside pursuits than when they were married.

The LES revealed that 12 separated mothers rated a positive change in their "usual type and/or amount of recreation" over the past 12 months as opposed to five who reported a negative change and two found this change to be neutral. 
For married mothers, two reported a positive change in recreation and one a negative change. (One married mother reported the change was neutral.) Significantly more separated mothers reported positive change, $\chi^{2}(1, N=76)=8.8, p<$ .005 .

In addition, 17 separated mothers reported a "major change in social activities, e.g., parties, movies, visiting [increased or decreased participation]" to be a positive event; nine reported this to change in a negative way. Two married mothers found a positive change in social activities, six found a negative change, and one found the change to be neutral. Again, the difference between the two groups experiencing positive changes was significant, $\chi^{2}(1, N=$ 76) $=15.8, p<.001$.

The pattern of results from the LES suggests that separated mothers are more active outside the home than are married mothers. Similarly, in the interviews separated mothers reported that they went out without the children significantly more often than did married mothers, $\chi^{2}(1, N$ $=76)=15.59, p<.001$. Twenty of the 38 separated mothers $(53 \%)$ reported that they managed to do this on a weekly basis. Among the 38 married mothers, only four (11\%) reported weekly outings.

The negative change in social activities reported by some married mothers may reflect reduced outings during the first years of a child's birth due to financial and practical difficulties. For some of the separated mothers, the change from having to arrange events with a partner to doing things on their own seemed to bring them a sense of freedom. One woman with two boys aged 47 months and 28 months said, "I'm reliving my teens."

I mean we never used to really go anywhere. We'd just stay in all weekend. But now, we [mother and children] go out. We go to my mum's or we go to my friend's. When I was with Fred, I wouldn't even dream of doing that. (Interviewer: Why?) I don't know why. I don't know why, but I just wouldn't dream of it. Now I think, 'hmm, want to do something, just go and do it'. Whereas before, I would never, ever do that. I wouldn't. Occasionally I would, but nothing like I do now. You know, I like - I mean sometimes it's awful being on your own, but other times I think, 'I can just do what I want'. And I don't have to worry about anybody else but the kids. [26-year-old full-time mother with a 36-month-old son and a 23-month-old daughter. Her ex-husband is a builder.]
Raising children on their own with little help was sometimes a gratifying experience for the mothers. Although almost all of them acknowledged the extreme difficulty of parenting without a partner, many mothers reported that they actually were coping rather well, thank you.

I feel, sometimes, I feel that I'm a really amazing person, I really do.... In general I feel great, knowing that I'm coping. And I am coping and I will because I'm determined to. I'm not going to let this thing beat me. [24-year-old full-time mother with two daughters aged 5- and 21-months. Her exhusband manages a pub.]

\section{Relations between life experience ratings and other measures}

The final part of the results section examines the links between a number of measures which assess the adjustment of the mother-child relationship (mother-child attachment), the mother's perceived stress as a parent (the Parenting Stress Index) and in her relationship with the child's father, the child's temperament and the child's development as measured by a standardized test. Having explored the links between the LES and responses to the interview questions, the rest of this section examines whether the life experience measures are correlated with a range of factors concerning the child's and the mother's adjustment and also the mother-child relationship. Table 1 presents the correlations between the LES positive and negative scores (in the two left hand columns) and four other measures. It shows, first, that a negative (or higher) score on the Dyadic Adjustment Scale is associated with rating fewer recent life events as positive and more as negative and also more parenting stress. Secondly, a mother's evaluation of recent experiences as negative was related to both greater experience of stresses in parenting and a poorer relationship with the child's father. Thirdly, the correlations in the three right hand columns show that parenting stress is related to poor adjustment in the parental relationship and a more negative maternal account of the child's temperament. However, the correlations in Table 1 are for the sample as a whole, without taking into consideration the fact that marital status accounts for differences in life experiences, as described above.

In order to investigate the relative influences of the factors described in Table 1 upon the mothers' experiences of life

Table 1

The Relationship Between the Two Life-Experience Measures and Assesments of Maternal Adjustment and Child Development

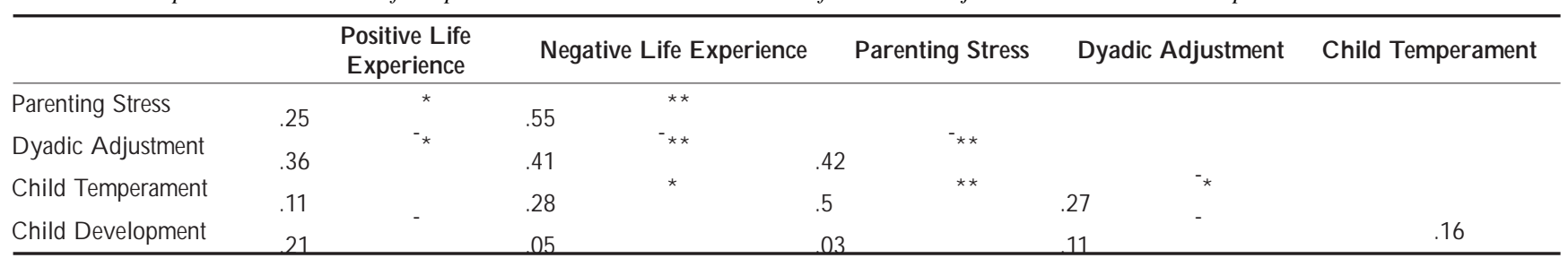

Note. Parenting Stress and Dyadic Adjustment are scored from positive to negative. So, for example, the higher the Dyadic Adjustment score the more negatively a respondent rates the relationship. The scales of Child Temperament and Child Development are positively scored.

$* p<.05 \quad * * p<.01$ 
Table 2

Hierarchical Regression of Negative Life Experiences on Marital Status, Mother-Child Attachment and the Remaining Explanatory Variables

\begin{tabular}{lcccrc}
\hline $\begin{array}{l}\text { Structural and } \\
\text { Explanatory Variables }\end{array}$ & $\begin{array}{c}\text { Partial } \\
\text { Correlation }\end{array}$ & BETA & $\boldsymbol{\beta}$ & $\mathbf{t ( 6 3 )}$ & $\mathbf{p}$ \\
\hline Status & 41 & 53 & 9.9 & 3.56 & .001 \\
A ttachment & -.14 & -.12 & -2.34 & -1.20 & .23 \\
Parental Stress & -14 & -.39 & -.07 & 3.31 & .002 \\
Dyadic A djustment & -.18 & -.17 & -.05 & 1.12 & .27 \\
Child Temperament & -.15 & -.18 & -.09 & 1.48 & .14 \\
Child Development & -.38 & -.12 & -.11 & -1.17 & .24 \\
\hline
\end{tabular}

events, two hierarchical (sequential) regressions were carried out, one for positive life experiences and the second for negative life experiences. The mothers' scores on each measure were regressed onto marital status, followed by a second bivariate measure, secure vs. insecure mother-child attachment, and then the other variables listed in Table 1. First, we examine the regression for positive life events. When the scores were regressed onto marital status this was significant, $R^{2}=$ $.17, F(1,68)=15.32, p<.001$, but when the other factors were added the additional influence was marginal (Total $R^{2}=$ .22) and none of the factors, contributed unique variance to the experience of life events as positive.

When the scores for the negative life experiences were loaded into the regression, a different picture emerged. As with positive life experiences the effect of status alone was significant, $R^{2}=.21, F(1,68)=8.75, p<.0001$. When the other variables were added to the equation the model remained significant and $R^{2}$ increased to .4 with the model remaining significant, $F(6,63)=20.45, p<.0001$. As Table 2 shows this was accounted for by the addition of the scores on the Parental Stress Index - the greater the parental stress the more negative experiences reported.

Following the significant result concerning Parenting Stress, further correlations were conducted to explore the relationship between the three sub-domains of this measure (the Child Domain, the Mother Domain, and the Demographic Domain) and negative evaluation of recent life experiences. All the sub-domains were significantly correlated with negative life events (all $p s<.05$ ) but a standard multiple regression did not reveal that one explanatory variable provided unique contributions to the equation. We may conclude that stress relating to parenting (the Mother Domain), the child, and general life stresses each related to the mother's experiences of life events, although of course the direction of causality is not discernible.

\section{Discussion}

Until relatively recently it was often assumed that disturbance in a resident parent and the lack of a second parent, usually a father-figure, produced insufficient stability for the child. Wallerstein and Blakeslee (1989, p. 35), for example, claim that divorced mothers "may well confuse their own needs with those of their children," lowering the quality of their parental input. The lack of a father-figure was thought to produce insufficient role modeling for the preschool child (e.g.,
Biller, 1981). In addition, an increase in non-normative life experiences was assumed to correlate with higher disturbance in the child (Goodyer, 1990). The results presented in this study support recent shifts in the literature on divorce away from a purely negative interpretation of maternal adjustment to resident/custodial parenting after separation.

In keeping with previous studies, the data show that the year after separation is characterised by an increase in the number of life experiences which have traditionally been associated with family problems. Previous interpretations of many of the events suggested that separated mothers were more likely to consider that these experiences have a negative influence upon themselves and their families. However, the data also appear to show that a more complex interpretation of such events is in order, as the higher positive change scores in the separated sample indicate. For example, on the issue of conflict with their ex-spouse it has been noted that almost one-quarter of the separated mothers reported a positive change even though significantly more separated than married mothers reported negative change. Similarly, for some, change in social support is considered negative, while for an equally large group, such change was deemed to be positive. Some people may feel "better off" (Olson \& Haynes, 1993), particularly if they leave a marriage which is highly conflictual or even violent. The contrasts between different mothers' experiences and within each account have two implications.

The first concerns the analysis of the impact of events surrounding marital separation. Standardised measures like the LES enable researchers to go beyond recording the number of events reported and the respondent's negative reaction to such experiences. The data presented in this study suggest that more attention needs to be paid to the experience of positive change and the mix of pluses and minuses that comprise life events (following Smart \& Neale, 1998). Such a balance has been somewhat neglected in psychological research. Sarason et al. (1978) recommended that use be made of the negative and total scores from the LES, because they were more stable than the positive scores and were more highly correlated with measures of anxiety and depression. However, they did not appear to relate the positive scale to any external criteria. The close correspondence between the LES and interview data suggest that both the negative and positive scales are valid and that together they provide a more representative picture of experiences after marital separation. Indeed, the complementarity between the interview and questionnaire suggests that such a combination may be used to good effect in future research. The LES was administered first. As a standardised measure it was important not to contaminate responses to individual questions. In the interview, respondents were allowed and encouraged to elaborate upon the complexities of their recent experiences having already demonstrated the diversity of their interpretations of different life experiences in the LES. As in the case of their mixed reactions to increased support from their families of origin, the interview was able to demonstrate the complexity of individual pathways through separation. Contrasts within and 
between mothers' accounts might provide critical data for illuminating such pathways.

The second implication of the results is that the recent shift towards a more balanced view of the divorce process seems to be more appropriate. As stated in the Introduction, not all children experience problems after parental separation, although of course come do (Hetherington, Bridges, \& Isabella, 1998). While there is a relative shortage of data on young children (Mayes \& Molitor-Siegl, 1999), the effects on preschoolers change over time (Hetherington, Cox, \& Cox, 1982). The responses to the LES and interview reflections suggested that mothers employ a kind of cost-benefit analysis in which they set the gains of separation against the losses of the relationship with their spouse and the problems of moving home, lower incomes, and the mixed reactions of family and friends. For example, it is well known that poverty besets single-parent families and has negative effects (Emery \& Coiro, 1997), but little is known about the division of resources within such families before separation and whether there are systematic differences between families above and below the breadline. It is not necessarily the case that financial resources are distributed between spouses (e.g., Brannen \& Wilson, 1987). Given that respondents on the LES check only a subset of events and the polarity of the items is mixed to avoid response bias, it is difficult to quantify whether the mixture of positive results which has been demonstrated within the sample as a whole was reported by individual mothers. An examination of individuals' responses confirmed that they had scored a mixture of positive and negative reactions to events.

It is possible that the results reported here may be restricted to mothers with a young preschool child and further research on samples with older children should be conducted to test their generalizablity, particularly as welfare provision in the United Kingdom may be different from countries. The possibility of a bias in maternal reporting should also be considered. It might be that separated women evaluate some changes as a result of life events in divorce as positive to reduce the dissonance caused by the process. However, this is unlikely for three reasons. In the first place in the interviews mothers were questioned at length about their experiences and they seemed to give very detailed and coherent accounts of particular events. The quotations cited in this paper provide brief examples of this coherence. Secondly, and perhaps more importantly, data from the maternal interviews which are not reported here, like mothers' assessments of the child's psychological development, tally with standardised test data from those children (see Table 1 and also Kier \& Lewis, 1997). Thirdly, the suggestion of bias in maternal accounts cannot explain the mixture of positive and negative scores on the LES. As a result, we suggest that these maternal accounts should be treated as valid. Like these mothers we suggest that theoretical reflections on the divorce process and maternal life experiences should look more broadly at the adjustment process after separation. Cost-benefit analyses would seem best to capture the adjustment of mothers to the life experiences involved in marital separation.
The analyses reported in Tables 1 and 2 support the contention that the benefits and costs of divorce should be considered in tandem. In addition, the finding that marital separation is closely related to a negative experience of events and a concern with one's ability to parent (see Table 2) raises some issues which need further exploration and ties in with recent theoretical claims about the need for an individual differences approach to the effects of divorce on families (Forgatch, Patterson, \& Ray, 1996; Grych \& Fincham, 1999), particularly the role of stress on the parent's skills as a parent (Emery \& Coiro, 1997). There is convergent evidence from longitudinal research (Pett, Wampold, Turner, \& VaughanCole, 1999) that the effects of divorce are channelled through maternal strain and the quality of mother-child interaction. We also know (e.g., Erel \& Burman, 1995) that the continuing relationship between parents is intricately related to the child's development. The evidence reported in this study reveals that maternal experiences of negative life events, particularly in the divorced group, are closely linked to their feelings of how they are coping as parents. This suggests that research and therapeutic interventions should look more closely at individual differences in the way resident (custodial) parents cope with the experiences which necessarily accompany parental separation. That some life-experiences are perceived in positive terms by some suggests that parental separation per se is only one factor in a complex network of influences on children and their parents.

\section{References}

Abidin, R. R. (1982). The Parenting Stress Index (PSI): A review of research. Charlottesville: Institute of Clinical Psychology.

Ainsworth, M. D. S., \& Wittig, B. A. (1969). Attachment and exploratory behaviour of one year olds in a strange situation. In B. M. Foss (Ed.), Determinants of infant behaviour IV. London: Methuen.

Allison, P. D., \& Furstenberg, F. F. Jr. (1989). How marital dissolution affects children: Variations by age and sex. Developmental Psychology, 25, 540-549.

Amato, P. R., \& Keith, B. (1991). Parental divorce and the wellbeing of children: A meta-analysis. Psychological Bulletin, 110, 26-46.

Amato, P. R. (1993). Children's adjustment to divorce: Theories, hypotheses, and empirical support. Journal of Marriage and the Family, 55, 23-38.

Bates, J. E., Freedland, C. A. B., \& Lounsbury, M. L. (1979). Measurement of infant difficultness. Child Development, 50, 794803.

Biller, H. B. (1981). Father absence, divorce and personality development. In M. E. Lamb (Ed.), The Role of the Father in Child Development (2nd ed., pp. 489-552). Chichester: Wiley.

Blechman, E. A. (1982). Are children with one parent at psychological risk? A methodological review. Journal of Marriage and the Family, 44, 179-195.

Brannen, J., \& Wilson, G. (1987). Give and take in families. London: Allen \& Unwin. 
Brown, C. (1994). The impact of divorce on families: The Australian experience. Family and Conciliation Courts Review, 32, 149-167.

Burghes, L. (1994). Lone parenthood and family disruption: The outcomes for children (Occasional paper 18). London: Family Policy Studies Centre.

Burgoyne, J., Ormrod, R., \& Richards, M. (1987). Divorce matters. Middlesex, England: Penguin Books.

Cherlin, A. J., Furstenberg, F. F., Chase-Lansdale, P. L., Kiernan, K., Robins, P. K., Morrison, D. R., \& Teitler, J. O. (1991). Longitudinal studies of effects of divorce on children in Great Britain and the U.S. Science, 252, 1386-1389.

Cockett, M., \& Tripp, J. (1994). The Exeter family study: Family breakdown and its impact on children. Exeter: University of Exeter Press.

Colletta, N. D. (1979). Support systems after divorce: Incidence and impact. Journal of Marriage and the Family, 41, 837-846.

Coontz, S. (1992). The way we never were: American families and the nostalgia trap. New York: Basic Books.

Cowan, C. P., \& Cowan, P. A. (1992). When partners become parents: The big life change for couples. New York: Basic Books.

DeGarmo, D. S., \& Forgatch, M. S. (1999). Contexts and predictors of changing maternal parenting practices in diverse family structures: A social interactional perspective of risk and resilience. In E. M. Hetherington (Ed.), Coping with divorce, single parenting and remarriage: A risk and resiliency perspective (pp. 227-252). Hillsdale, NJ: Lawrence Erlbaum.

Emery, R. E, \& Coiro, M. J. (1997). Some costs of coping: Stress and distress among children from divorced families. In. D. Cicchetti \& S. L. Toth (Eds.), Rochester Symposium on Developmental Psychology: Vol. 8. Developmental perspectives on trauma: Theory, research, and intervention (pp. 435-462). Rochester: University of Rochester Press.

Erel, O., \& Burman, B. (1995). Interrelatedness of marital and parent-child relations: A meta-analytic review. Psychological Bulletin, 118, 108-132.

Forgatch, M. S., Patterson, G. R., \& Ray, J. A. (1996). Divorce and boys' adjustment problems: Two paths with a single model. In E. M. Hetherington \& E. A. Blechman (Eds.), Stress, coping, and resiliency in children and families. Family research consortium: Advances in family research (pp. 67-105). Mahwah, NJ: Lawrence Erlbaum.

Forgatch, M. S., Patterson, G. R., \& Skinner, M. L. (1988). A mediational model for the effect of divorce on antisocial behavior in boys. In E. M. Hetherington \& J. D. Arasteh (Eds.), Impact of divorce, single parenting, and stepparenting on children (pp. 135-154). Hillsdale, NJ: Lawrence Erlbaum.

Furstenberg, F. (1990). Coming of age in a changing family system. In S. Feldman \& G. Elliott (Eds.), At the threshold: The developing adolescent (pp 147-170). Cambridge: Harvard University Press.

Garmezy, N., \& Rutter, M. (1983). Stress, coping, and development in children. New York: McGraw-Hill.

Gately, D., \& Schwebel, A. I. (1992). Favourable outcomes in children after parental divorce. Journal of Divorce and Remarriage, $18,57-78$.
Gittins, D. (1993). The family in question. Basingstoke: Macmillan.

Goodyer, I. (1990). Family relationships, life events and childhood psychopathology. Journal of Child Psychology and Psychiatry, 31, 161-192.

Gringlas, M., \& Weinraub, M. (1995). The more things change. Single parenting revisited. Journal of Family Issues, 16, 29-52.

Griffiths, R. (1954). The abilities of babies. London: University of London Press.

Grych, J. H., \& Fincham, F. D. (1999). Children of single parents and divorce. In W. K. Silverman \& T. H. Ollendick (Eds.), Developmental issues in the clinical treatment of children (pp. 321-341). Boston: Allyn \& Bacon.

Guttman, J. (1993). Divorce in psychosocial perspective: Theory and research. Hillsdale, NJ: LEA.

Harding, L. F. (1993). "Alarm" vs. "liberation"? Responses to the increase in lone parents - part 2. Journal of Social Welfare and Family Law, 2, 174-184.

Hernandez, D. J. (1994). Children's changing access to resources: A historical perspective. Social Policy Report, Society for Research in Child Development, VIII (1), 1-23.

Hetherington, E. M. (Ed.). (1999a). Coping with divorce, single parenting and remarriage: A risk and resiliency perspective. Hillsdale, NJ: Lawrence Erlbaum.

Hetherington, E. M. (1999b). Should we stay together for the sake of the children? In E. M. Hetherington (Ed.), Coping with divorce, single parenting and remarriage: A risk and resiliency perspective (pp. 117-146). Hillsdale, NJ: Lawrence Erlbaum.

Hetherington, E. M., Bridges, M., \& Isabella, G. M. (1998). What matters? What does not? Five perspectives on the association between marital transitions and children's adjustment. American Psychologist, 53, 167-184.

Hetherington, E. M., Cox, M., \& Cox., R. (1982). Effects of divorce on parents children. In M. E. Lamb (Ed.), Nontraditional Families (pp. 233-288). Hillsdale, NJ: Lawrence Erlbaum.

Hodges, W. F., Landis, T., Day, E., \& Oderberg, N. (1991). Infant and toddlers and post divorce parental access: An initial exploration. Journal of Divorce and Remarriage, 17, 239-252.

Hollingshead, A. B. (1975). Four factor index of social status. Unpublished working paper. Yale University.

Hutchinson, R. L., \& Spangler-Hirsch, S. L. (1989). Children of divorce and single-parent lifestyles: Facilitating well-being. Journal of Divorce, 12, 5-24.

Jenkins, J. M., \& Smith, M. A. (1993). A prospective study of behavioural disturbance in children who subsequently experience parental divorce: A research note. Journal of Divorce and Remarriage, 19, 143-160.

Kier, C., \& Lewis, C. (1997). Infant-mother attachment in separated and married families. Journal of Divorce and Remarriage, 26, 185-194.

Kurdek, L. A. (1987). Children's adjustment to parental divorce: An ecological perspective. In J. P. Vincent (Ed.), Advances in family intervention, assessment, and theory, IV. Greenwich, CT: JAI Press.

Kurdek, L. A. (1991). Differences in ratings of children's adjustment by married mothers experiencing low marital conflict, married mothers experiencing high marital conflict, and di- 
vorced single mothers: A nationwide study. Journal of Applied Developmental Psychology, 12, 289-305.

Lewis, C., Papacosta, A., \& Warin, J. (in press) Cohabitation, separation and fatherhood. London: Family Policy Study Centre.

Maclean, M. (1991). Surviving divorce. London: Macmillan Education.

Mayes, L. C., \& Molitor-Siegl, A. (1999). The impact of divorce on infants and very young children. In R. M. Galatzer-Levy \& L. Kraus (Eds.), The scientific basis of child custody decisions (pp. 188-204). New York: John Wiley.

McLanahan, S. S. (1999). Father absence and the welfare of children. In E. M. Hetherington (Ed.), Coping with divorce, single parenting and remarriage: A risk and resiliency perspective (pp. 117-145). Hillsdale, NJ: Lawrence Erlbaum.

Olson, M. R., \& Haynes, J. A. (1993). Successful single parents. Families in Society, 74, 259-267.

Pett, M. A., Wampold, B. E., Turner, C. W., \& Vaughan-Cole, B. (1999). Paths of influence of divorce on preschool children's psychosocial adjustment. Journal of Family Psychology, 13,145164.

Potter, J., \& Wetherell, M. (1987). Discourse and social psychology: Beyond attitudes and behaviour. London: Sage.

Rapoport, R, Rapoport, R. N., \& Strellitz, Z. (1975). Fathers, mothers, and others. London: Routledge.

Richards, L. N., \& Schmiege, C. J. (1993). Problems and strengths of single-parent families: Implications for practice and policy. Family Relations, 42, 277-285.

Richards, M. P. M. (1995). The international year of the family family research. The Psychologist, 8, 17-20.

Rodgers, B., \& Pryor, J. (1998). Divorce and separation: The outcomes for children. York: Joseph Rowntree Foundation.

Sarason, I. G., Johnson, J. H., \& Siegel, J. M. (1978). Assessing the impact of life changes: Development of the Life Experi- ences Survey. Journal of Consulting and Clinical Psychology, 46, 932-946.

Schlesinger, B. (1994, April). Children in one-parent families: A review. Paper presented at the XXXIth Seminar, Committee on Family Research, International Sociological Association: Children and Families: Research and Policy. London.

Smart, C., \& Neale, B. (1998). Family fragments. Cambridge: Polity Press.

Spanier, G. B. (1976). Measuring dyadic adjustment: New sacles for assessing the quality of marriage and similar dyads. Journal of Marriage and the Family, 38, 15-28.

Stolberg, A. L., \& Anker, J. M. (1983). Cognitive and behavioral changes in children resulting from parental divorce and consequent environmental changes. Journal of Divorce, 7, 23-41.

Summers, M., Summers, C. R., \& Ascione, F. R. (1993). A comparison of sibling interaction in intact and single-parent families. Journal of Divorce and Remarriage, 20 (1/2), 215-227.

van Every, J. (1991). Who is 'the family'? The assumptions of British social policy. Critical Social Policy, 33, 62-78.

Veevers, J. E. (1991). Traumas vs. stress: A paradigm of positive vs. negative divorce outcomes. Journal of Divorce and Remarriage, $15,99-126$.

Wallerstein, J. S., \& Blakeslee, S. (1989). Second chances. London: Corgi Books.

Wallerstein, J. S., Lewis, J., \& Blakeslee, S. (2000). The unexpected legacy of divorce: A 25 year landmark study. New York: Hyperion.

Zill, N., Morrison, D. R., \& Coiro, M. J. (1993). Long-term effects of parental divorce on parent-child relationships, adjustment, and achievement in young adulthood. Journal of Family Psychology, 7, 91-103. 